УДК 340.15(477) +342.41(477)

Каніщев Г. Ю.

doi: $10.32620 /$ gch.2019.2.05

\title{
КОНСТИТУЦІОНАЛІЗМ У ВИКЛАДАННІ «ІСТОРІЇ ДЕРЖАВИ І ПРАВА УКРАЇНИ» (ДОМОДЕРНИЙ ПЕРІОД)
}

Статтю присвячено питанням викладання історії конституціоналізму в Україні в навчальному курсі «Історія держави $і$ права України». Автора цікавлять питання історичної еволюиії конституціоналізму в України.

Ключові слова: конституціоналізм, права людини, Конституція України, історична полідержавність украӥнського народу.

The article is dedicated to teaching the history of constitutionalism in the training course «History of State and law of Ukraine». The author is interested in the problem of historical evolution of constitutionalism in Ukraine.

Keywords: constitutionalism, human rights, The Constitution of Ukraine, historical polistatehood of the Ukrainian people.

Формулювання проблеми. Питання конституціоналізму, тобто системи відносин між суспільством і державою (у першу чергу щодо дотримання прав і свобод людини і громадянина) на основі конституції й законів, що доповнюють або замінюють їі, $\epsilon$ одним з ключових питань історико-правових досліджень в Україні.

Україна всі роки після ухвалення своєї Конституції на кожному кроці подавала приклади нехтування нею як з боку звичайних громадян, так і з боку публічної влади (держави й місцевого самоврядування). Конституція сприймалася (і сприймається) радше як «парадний фасад» української держави, що повинен прикривати собою свавілля влади й правовий нігілізм суспільства. Це й призвело, на нашу думку, до всебічної кризи й українського суспільства, й української влади, яку спостерігаємо зараз.

Убачаємо вихід із кризи у «поверненні до Конституції», тобто в дотриманні іï норм та їх активному використанні для захисту прав і свобод людини й громадянина. Знання й уміння тлумачити Конституцію держави для захисту своїх прав $\epsilon$ принципово важливими для українських громадян.

Для цього, на нашу думку, важливо розглянути конституціоналізм не тільки як політичну доктрину (про це йшлося вище), а й доктрину історичну, тобто як історію законодавства, охоплюючи великий за хронологією період, який передував появі сучасних конституцій. Цей період ми позначаємо як домодерний (до формування сучасних національних держав). Велику роль у цьому, уважаємо, належить історії держави й права України як науці й навчальній дисципліні.

Mema cmammi - висвітлення історії конституціоналізму на території сучасної України в домодерний період розвитку української державності й права. Завдання cmammi - розкриття взаємозв'язку історії держави і права України та конституційного права України через аналіз змісту державних законодавчих актів, які мали значення 
конституцій для тодішнього населення українських земель у складі різних держав.

Аналіз останніх досліджень $і$ публікацій за темою. Підгрунтя статті складають дослідження й публікації з історії держави і права України, зокрема, навчальна література, а також дослідження й публікації 3 конституційного права, зокрема коментарі до Конституції України та тексти конституцій інших держав. Останні використано для порівняння з Конституцією України. Серед досліджень і публікацій 3 історії держави і права України вважаємо за потрібне виділити підручник для студентів під редакцією В.Д. Гончаренка. Його актуальність для нашої статті полягає в погляді на історію держави і права України як на історію різних державних утворень і, відповідно, їх правових систем. Ця теза авторів підручника дозволяє нам спиратися на неї в обгрунтуванні концепції історичної полідержавності українського народу.

Серед правових досліджень вважаємо за необхідне звернути увагу на науковопрактичний коментар Конституції України О.В. Петришина та В.Ф. Погорілка. Він має значення для нашої статті 3 погляду обгрунтування права громадян вільно тлумачити Основний Закон держави. А значить, i обгрунтовувати вищезгадану концепцію історичної полідержавності українського народу вже не тільки 3 історичного, а й з політико-правового погляду.

Виклад основного матеріалу. Історію держави і права України можна вважати однією 3 провідних навчальних дисциплін для сучасних юристів. Її метою $\epsilon$ ознайомлення майбутніх фахівців із тим історичним досвідом розвитку державності і права на території сучасної України, що прямо або опосередковано впливає й на сучасний стан і якість публічної влади в нашій державі, на відносини між державою й громадянами, на становище України на міжнародній арені, іiі імідж у світі тощо.

Орієнтиром для дослідження різноманітних проблем історії української державності і права є Конституція України. Її значення тут полягає в такому. Поперше, вона визначає саму легітимність існування української держави як такої, спираючись «на багатовікову історію українського державотворення» (цитата 3 преамбули Основного Закону) [8]. Слід зазначити що Конституція України у своїй преамбулі не містить конкретних указівок на те, які саме державні утворення минулого (i їх правові системи) слід вважати українськими, як це зроблено наприклад, у Конституції Республіки Хорватія [9].

Відсутність таких уточнень у преамбулі української Конституції робить можливим і необхідним іiі тлумачення щодо того, які саме державні утворення слід мати на увазі під «багатовіковою історією українського державотворення». I тут орієнтиром, уважаємо, повинні бути слова, із яких починається преамбула Конституції, а саме: «Верховна Рада України від імені Українського народу громадян України всіх національностей...» [8]. Таке визначення українського народу одноголосно тлумачиться фахівцями-юристами як політична, а не етнічна нація, спільнота всіх громадян України [12].

Тому стверджуємо, що «багатовікова історія українського державотворення» (а значить, об’єкт дослідження і викладання для історії держави і права України) - це історія всіх держав на території сучасної України від давньої Скіфії та античних 
держав Північного Причорномор'я до СРСР - УРСР включно [7, с. 48]. Причому, ураховуючи неоднозначність, «розмитість» самого терміна «держава» протягом історії людства стверджуємо, що сюди слід зарахувати не тільки «суверенні» держави в сучасному розумінні цього терміну, а й «несуверенні», «васальні» адміністративнотериторіальні утворення 3 більшим або меншим рівнем автономії у складі інших держав [4, с. 90].

По-друге, Конституція України надає орієнтир щодо управління територією держави відповідно до вищезгаданого тлумачення історії українського державотворення. Він міститься в ст. 132 Основного Закону розділу IX «Територіальний устрій України». Маємо на увазі слова, що територіальний устрій України повинен базуватися на урахуванні історичних особливостей, етнічних та культурних традицій іiі регіонів [8]. Значить, держава Україна зобов'язується у своїй Конституції під час поточної управлінської діяльності враховувати особливості минулого розвитку різних територій України в складі різних держав, що охоплювали ці території своєю владою, а також ураховувати вплив їх правових систем на політичну й правову культуру сучасних українців.

Вищезгадані явища ми вважаємо за необхідне позначити поняттям «історична полідержавність українського народу». Центральний термін тут - полідержавність. Він, на нашу думку, відтворює факт політичного розвитку українців у складі різних держав, утворених як власне українцями, так і іншими народами на території сучасної України. Слово «історична» вказує, що йдеться про історичне минуле українського народу. Нарешті, поняття «український народ» тлумачиться нами згідно 3 Конституцією, тобто як політична спільнота українських громадян усіх національностей. Це, уважаємо, допомагає поєднати історію власне українських державних утворень (як суверенних, так і автономних) 3 історією держав, утворених на сучасній українській території іншими народами, і створити таким чином цілісну картину історичної еволюції української державності та права у зв’язку із всесвітньоісторичним процесом еволюції держави і права (насамперед, у східній частині європейського континенту).

Поняття «історична полідержавність українського народу» ми вважаємо належним як до історії держави і права України, так і до конституційного права України. Його значення для історії держави і права України полягає, на нашу думку, у розкритті значення сучасної української держави як історичного спадкоємця всіх колишніх держав на території сучасної України. Його значення для конституційного права України полягає в тому, що саме завдяки цьому поняттю, уважаємо, розкривається зміст терміна «багатовікова історія українського державотворення» в преамбулі Конституції України й тим самим легітимізується сучасна українська держава як така в очах українських громадян усіх національностей. А отже, підводиться історичний грунт під поняття українського народу - громадян України всіх національностей. Останнє ж, на нашу думку, є ключовим поняттям для формування в Україні політичної, громадянської нації, для зміцнення єдності i, відповідно, територіальної цілісності держави Україна.

Таким чином, Конституція України як іiі Основний Закон $є$ фундаментальним 
джерелом для викладачів і студентів-правників у процесі дослідження різноманітних проблем історії української державності та права, а історія держави і права України, своєю чергою, є фундаментальним джерелом для розуміння й тлумачення української Конституції.

Відповідно до вищезазначеного торкнемося питання, яке неминуче постає під час дослідження історії держави і права України, - проблеми бездержавності української нації. Проблема бездержавності української нації полягає у пропагуванні, у першу чергу в історичній та історико-правовій літературі, а також у публіцистиці, ідеї відсутності в українців (причому під українцями мається на увазі саме український етнос) власної незалежної держави протягом досить великого історичного періоду. Ми категорично заперечуємо цю ідею як таку, що суперечить Конституції України, а саме ідеї багатовікової історії українського державотворення. Натомість стверджуємо, що український народ (громадяни України всіх національностей) був державно-організованим народом завжди, без переривання своєї державотворчої традиції. Інша річ, що його державність не завжди була «своєю», тобто утвореною власне українцями. Часто це були інші держави, які, як уже зазначалося вище, розповсюджували свою владу на всю або на окремі частини території сучасної України. Утім, для українського етносу це пом'якшувалося такими обставинами. По-перше, він часто зберігав усередині цих країн свою державність на засадах федерації або автономії як форм реалізації права нації на самовизначення, наприклад, у формі Української РСР. По-друге, українці брали участь, часом дуже активну, в управлінні цими державами. Особливо це стосується Російської імперії і Радянського Союзу. Тим більше, що формально, тобто з юридичного погляду, Україна є правонаступницею СРСР - УРСР відповідно до Закону України № 1543-XII «Про правонаступництво України» від 12 вересня 1991 р. [14].

Саме такий погляд на зміст викладання історії держави і права України, на нашу думку, повністю відповідає Конституції нашої держави, розвиває й конкретизує основні їі положення, визначені в преамбулі Основного Закону України.

Що ж стосується бездержавності, то це явище в історії держави і права України, уважаємо, дійсно мало місце, однак зовсім не в тому вигляді, як це прийнято традиційно сприймати. Приєднуємося до думки, що терміном «бездержавність (бездержав'я, недержавність)» слід позначати два явища. По-перше, це стан суспільства, який характеризується відсутністю державних інституцій як таких [1]. Такий стан був характерний для первіснообщинного ладу. По-друге, терміном «бездержавність», уважаємо, слід позначати стан хаосу, безладу й безвладдя, що виникає внаслідок воєн, повстань тощо [1]. Утім, така ситуація не означала тривалого стану бездержавності, адже внаслідок вищезгаданих потрясінь одна форма державності заміщалася іншою. I хоча держави минулого, зокрема на території України, були недосконалими порівняно із сучасною державністю, вони значно прискорювали прогрес цивілізації порівняно із бездержавним періодом історії людства.

Тлумачення багатовікової історії українського державотворення як історії всіх держав на території сучасної України, своєю чергою, пов’язує історію держави i 
права України з історією держави і права зарубіжних країн, робить їі органічною частиною всесвітньо-історичного процесу державотворення. Історія держави і права України у такому випадку перестає бути заідеологізованою, «поза простором i часом», навчальною дисципліною. Саме так, на нашу думку, виникає можливість робити узагальнення в галузі теорії держави і права не тільки на матеріалі історії держави і права зарубіжних країн (як це зазвичай робиться), а й на матеріалі історії держави і права України. Уважаємо, що для українських студентів така інформація буде значно більш цікавою й актуальною, ніж приклади 3 історії зарубіжного державотворення, не пов'язані (або мало пов’язані) з Україною.

Прийняття тези щодо історичної полідержавності українського народу як основи дослідження й викладання історії держави і права України дозволяє розглядати у відповідному навчальному курсі та наукових публікаціях історичний досвід різних держав, які існували на території сучасної України протягом віків, зокрема, щодо розуміння й дотримання прав людини. На нашу думку, це питання обов'язково треба пов'язувати 3 питанням періодизації історії держави і права України. Зв'язок тут, уважаємо, такий: залежно від характеру державності й особливостей права в тут чи ту епоху розумілися й права, свободи й обов'язки людини та громадянина.

У зв'язку із цим звертаємо увагу на думку українського історика права Л. Окіншевича (1898-1980) щодо поділу історії українського права на право феодальної (X-XV ст.), станової (XVI - середина XIX ст.) і модерної (національної) держави (XIX-XX ст.) [3, с. 6]. Приєднуємося до думки, що позитивною рисою такої періодизації є зв'язок історії держави і права України 3 історією держави і права зарубіжних країн, у першу чергу європейських [3, с. 6].

Уважаємо за необхідне внести у вищезгадану періодизацію наступну корективу: об’єднати періоди феодальної та станової держави у єдиний - домодерний - період історії української державності та права. Усередині ж цього великого періоду доцільно, уважаємо, зберегти його поділ на феодальні та станові державу і право (додавши на початку підперіод рабовласницької держави та права). Обгрунтовуємо це необхідністю підкреслити радикальні зміни в розумінні й функціонуванні національної держави порівняно з державою попередніх епох, у тому числі й у першу чергу стосовно прав, свобод і обов'язків людини й громадянина. Основне завдання тут, уважаємо, прослідкувати взаємозв'язок між домодерною й модерною державністю та правом, зокрема з'ясувати актуальність домодерного періоду в історії держави і права України (у тому числі стосовно прав людини).

Розкриваючи зміст уявлень про права людини в домодерну епоху, слід підкреслити зв'язок цих уявлень з уявленнями тодішньої людини про державу та право взагалі. До останніх слід зарахувати такі фактори.

1. Сдиним джерелом державної влади вважалася воля Бога. Усе суспільство (i держава як головний елемент його політичної системи) уважалося творінням Бога та проявом його волі на землі. Термін «Закон» позначав насамперед волю Бога, сформульовану у священній книзі - Біблії. Земні закони (укази правителів тощо) повинні були відповідати Святому Письму.

2. Для людей домодерної епохи не існувало абстрактних понять «держава» та 
«право». Під державою розумілася державна влада, поточне управління в різних його проявах: суд, збирання податків, військова справа тощо. Для позначення державної влади різні народи вживали різні терміни. Так, давні греки з античних міст Північного Причорномор'я, які, власне, i започаткували державність на території сучасної України, уживали на позначення поточного державного управління слово «політія». У давніх слов'ян - предків сучасних українців, а також росіян і білорусів - на позначення державної влади вживалося слово «волость». Відповідно під «правом» розумівся або звичай (на ранніх етапах розвитку держави, наприклад, у давній Русі, коли державне законодавство ще не витіснило собою звичаєве право додержавного періоду), або, як згадувалося вище, закони (укази) й інші розпорядження правителів та їхніх намісників в окремих регіонах держави.

3. Критерієм легітимності державної влади слугувало дотримання правил іiі спадковості за династичним принципом і, відповідно, абсолютна перевага монархії як форми державного правління в домодерну епоху.

4. Критерієм формування території держави вважалося спадкове право тої чи тої династії (і окремих правителів) на відповідні території. А згадані вище терміни «політія» й особливо «волость» уживалися не тільки на позначення державної влади, а й території держави.

У той же час об’єднання в складі держави різних територій не означало їх уніфікації в межах держави. Усі регіони домодерної держави можна поділити за ступенем внутрішньодержавної автономії на регіони, які управлялися «унітарно», i регіони, що управлялися «федеративно», тобто мали в складі держави більший або менший рівень автономії.

5. Важливим елементом політики домодерного періоду був поділ населення держави на станові корпорації (у тому числі за конфесійною ознакою). Сама ж держава, формально єдина, насправді була строкатим конгломератом етнічних, мовних, конфесійних та інших елементів, що жили своїм політичним життям.

Відповідно, історія конституціоналізму на території сучасної України вважаємо, на нашу думку, повинна охоплювати такі моменти.

У Давній («Київській») Русі розвиток держави як політичної організації суспільства, побудованої на засадах суворої ієрархії, гостро ставив питання про права державних підданих. Можна стверджувати, що в часи Давньої Русі це питання було поставлене вперше в історії української державності та права. Ураховуючи менталітет середньовічної людини, наскрізь пронизаний релігійними уявленнями про довколишній світ і саму людину, немає нічого дивного в тому, що відповідь на поставлене питання тодішні люди шукали саме в релігійній площині, а саме в розв’язанні питання щодо політичної взаємодії («симфонії», за тодішньою термінологією) держави й Церкви. Тут потрібно усвідомлювати, що Церква в середньовічному суспільстві була не лише власне релігійною, а й політичною організацією з власною ієрархією, а отже, конкурентом держави щодо політичного впливу на людей.

Відповіддю на питання про «симфонію» держави й Церкви в Давній Русі, уважаємо, були «Устави» Володимира Великого та Ярослава Мудрого [10]. Слід 
звернути увагу на їхнє основне завдання - розмежування власне державної (світської) і церковної юрисдикції, а значить, правове визнання державою обмеженості своєї влади щодо державних підданих. Саме через цю особливість «Уставів» їх, на нашу думку, можна вважати першими пам'ятками конституційного характеру в історії держави і права України, що стосуються прав людини.

Якщо «Устави» регулювали відносини держави та іiі підданих стосовно церковної юрисдикції, то «Руська Правда» регулювала ці відносини стосовно світських правових норм, а саме, розв'язувала завдання щодо розмежування й взаємодії звичаєвого та писаного права [6, с. 4]. Важливо розуміти, що «Руська Правда» - це збірник норм звичаєвого права, доповненого новими державними писаними нормами. А це означає, що, зафіксувавши відповідні норми в письмовому вигляді й проголошуючи їх загальнообов'язковими, давньоруська держава в особі великого київського князя тим самим обмежувала й власну владу щодо своїх підданих.

Отже, «Устави» Володимира Великого та Ярослава Мудрого в комплексі 3 «Руською Правдою» слід, на нашу думку, уважати першою українською «конституцією». Їх значення полягало в самообмеженні державної влади на користь прав іiі підданих в умовах інтенсивного формування держави як такої й розповсюдження ii впливу на різні сфери життя людей. Тим самим закладалася основа конституційної традиції, зокрема щодо відображення прав і свобод людини.

У Великому князівстві Литовському велике значення для прав і свобод людини мали спочатку обласні, а потім і загальнодержавні привілеї, що були згодом доповнені статутним правом (Литовськими статутами 1529, 1566 та 1588 рр.) [13; 15]. Значення вищезгаданих нормативно-правових актів для історичної традиції українського конституціоналізму щодо прав людини полягає, на нашу думку, у такому. Це було залучення українських земель до системи європейського права з його обмеженням влади володаря правами підданих. Саме така держава могла вважатися «republica bene ordinata» - «добре впорядкованою державою».

Розглядаючи питання щодо прав людини на українських землях Речі Посполитої, слід звернути увагу на остаточне затвердження ідеї обмеження влади держави на користь прав ії підданих - станових, регіональних і конфесійних. Саме внаслідок цього Польсько-Литовську державу (Річ Посполиту) можна вважати «Republica bene ordinata», ідеал якої сформувався в попередні століття.

Найвищим проявом цього були нормативно-правові акти Речі Посполитої, що мали характер конституції. До них належать: а) Акт Варшавської конфедерації; б) «Генрикові артикули»; в) «Расtaconventa» (усі документи - 1573 р.) [2; 3, с. 56; 11].

Особливу увагу слід звернути на Акт Варшавської конфедерації - документ, що затверджував у Польсько-Литовській державі релігійну свободу - основу всіх інших, зокрема політичних, свобод в уявленні тодішніх людей[3, с. 56]. «Генрікові артикули» - акт, що окреслював обсяг повноважень короля (а в його особі - держави) стосовно «народу» (шляхти) [2]. Зміст «Артикулів...» доповнював «Pactaconventa» як список зобов'язань кожного конкретного монарха перед шляхтою [11].

Необхідно зазначити, що формування державного апарату центральної й 
місцевої влади в Речі Посполитій відбувалося з урахуванням інтересів різних станів. Це явище повністю відповідало уявленням тодішніх людей про соціальну структуру суспільства як сукупність різних соціальних груп (станів) із різним політичним становищем і правами стосовно одне одного й держави. Відповідно до цього органи публічної влади в місцевому управлінні Польсько-Литовської держави поділялися за становою ознакою: одні діяли в інтересах шляхти, другі - міщанства, а треті козацтва. Це впливало й на адміністративно-територіальний поділ держави. Так, адміністративно- територіальними одиницями шляхетського урядування були воєводства й повіти, міщанського - міста з Магдебурзьким правом, а козацького територія реєстрового козацького війська з центром у м. Трахтемирів (згодом - у Чигирині). Те, що згадані адміністративно-територіальні одиниці й відповідні органи і посадові особи діяли у станових інтересах, дає змогу характеризувати Річ Посполиту не просто як станову, а й як децентралізовану державу, що складалася зі станових автономій різного територіального рівня.

Розглядаючи питання конституціоналізму в часи української козацької державності XVII-XVIII ст., треба звернути увагу на гетьманські статті - акти державно-правового та міжнародно-правового характеру, що визначали устрій української гетьманської держави («Війська Запорозького обох сторін Дніпра») та іiі взаємовідносини 3 Російським (Московським) царством на період правління конкретного гетьмана [3, с. 78].

Щодо причин появи статей необхідно зазначити, що вони були наслідком глибокої кризи Польсько-Литовської держави у іiі відносинах 3 українським козацтвом. Кризи, яка 1648 р. вилилася в Хмельниччину й призвела до формування в південно-східній частині Речі Посполитої фактично нової держави - Війська Запорозького обох сторін Дніпра на чолі із виборними гетьманом та старшиною. Слід звернути увагу на неможливість співіснування українського козацького та шляхетського суспільного устрою в межах Польсько-Литовської держави. Ця обставина, власне, і призвела до відокремлення частини південно-східної «україни» Речі Посполитої (де внаслідок Хмельниччини запанував козацький устрій) та іiі наступного входження до Російського (Московського) царства на правах васальної держави - Війська Запорозького обох сторін Дніпра. Для правого оформлення нової політичної реальності й знадобилися «гетьманські статті». Вони були, по суті, спробою українського (козацького) суспільства реалізувати ідеал «Republica bene ordinata» в межах нової - Російської - державності, так би мовити, «з чистого аркуша».

Слід зауважити, що, незважаючи на поступове обмеження прав козацтва та інституцій публічної влади Війська Запорозького російським урядом, ці акти фіксували взаємні обов'язки Російської держави й українського населення (репрезентованого гетьманом і старшиною), були договором між ними, а отже, фіксували договірні відносини народу й держави [10]. Саме в цьому розумінні гетьманські статті слід уважати джерелом українського права. Регулюючи правові відносини найвищого («конституційного») змісту - відносини держави і суспільства вони тим самим були підгрунтям для тих правових актів, що стосувалися різних 
аспектів відносин усередині самого українського суспільства: цивільних, сімейношлюбних, кримінальних та ін. «Гетьманські статті», таким чином, формували правову культуру тодішніх українців загалом.

Розглядаючи це питання, необхідно також приділити увагу проблемі співставлення «статей» із «Конституцією» П. Орлика (1710р.), яку прийнято вважати першою українською конституцією. Тут слід зазначити, що, не зважаючи на демократичність свого змісту, «Конституція» П. Орлика не діяла на території Гетьманщини жодного дня, оскільки була укладена козацькою старшиною колишніми прихильниками I. Мазепи на чолі із самим П. Орликом - в еміграції, за межами тодішньої української держави. Гетьманські статті ж діяли на території Війська Запорозького протягом майже століття. Тому саме їх, а не «Конституцію» П. Орлика, уважаємо, потрібно розглядати як дійсні, реальні українські конституції того часу. До того ж, як свідчить матеріал попередніх тем, далеко не перші в історії України.

Вивчаючи матеріал за цією темою, необхідно пояснити й причини скасування дії статей. На нашу думку, такою причиною слід уважати внутрішню кризу самого козацтва як основної соціально-політичної опори згаданого права. Перші ознаки кризи, на нашу думку, проявилися вже під час Хмельниччини, адже іiі соціальною сутністю було загальне «покозачення» населення на шкоду іншим станам: міщанству, селянству й, особливо, шляхті. Тим самим руйнувався звичний становий порядок, притаманний державному устрою Речі Посполитої й у новій - козацькій - державі так i не відновлений. Крім того, Хмельниччина й подальша «Руїна» призвели до деформації правових відносин узагалі, до панування в суспільстві «кулачного права». I хоча, зрештою, війна припинилася, іiі наслідки проявилися згодом, у формі свавілля козацької старшини стосовно рядового козацтва, селян і міщан.

Саме це стало темою доповідної записки російського сановника в Україні, члена Малоросійської колегії Григорія Миколайовича Теплова (1717-1779). Будучи близьким другом і наставником гетьмана К.Г.Розумовського, Г.М. Теплов 1761 р. склав доповідну записку на ім'я імператриці Єлизавети Петрівни під назвою «О непорядках, которые происходят от злоупотребления прав и обыкновений, грамотами подтвержденных Малороссии» [16]. Особливо важливою, на нашу думку, є восьма його частина, що стосується кризових явищ литовсько-польського права в умовах Гетьманщини - явищ, які були передумовою наступних змін у державному устрої та праві України.

Розглядаючи питання щодо розвитку конституціоналізму після ліквідації козацької державності, слід звернути увагу на основну політичну обставину, що диктувала розвиток держави і права на українських землях: протягом другої половини XVIII ст. усі українські етнічні території були поглинені новими модерними державами-імперіями: Росією та Австрією. Це означало розповсюдження на українські землі державного устрою відповідних імперських держав. Насамперед це стосувалося Російської імперії - країни, до складу якої наприкінці XVIII ст. увійшло близько двох третин тодішньої української етнічної території.

Разом із тим слід розуміти, що це не призвело до припинення існування й 
подальшого розвитку українського суспільства як такого. Занепад козацтва протягом XVIII ст. призвів до появи інших станів: шляхти (дворянства), міщан і державних селян. I якщо говорити про нові, «імперські» умови існування українського суспільства, то слід зазначити, що воно успадкувало від попередньої, козацької, епохи центральну ідею - ідею боротьби за станові права. У нових умовах, що настали для українських станів у другій половині XVIII ст., вирішальною стала ідея захисту прав нових станів перед російським імперським урядом.

Ця тенденція знаходила відгук у самій Росії через кризу російської державності внаслідок політики Петра I (1682-1725). Незважаючи на великі успіхи в розвитку буквально всіх сфер суспільного життя - економіки, освіти, військової справи та державного управління, що вивели Росію в ряд великих європейських держав, петровський абсолютизм (необмежена влада монарха) наприкінці правління царя призвів до глибокої соціально-економічної, а згодом і до політичної кризи через посилення бюрократизації держави й збільшення податкового тиску на народ.

Усі ці обставини призвели до появи в Російській імперії нової політичної течії станового конституціоналізму. Це політичний рух за збереження й збільшення станових привілеїв (насамперед, дворянських) перед загрозою наступу абсолютизму, офіційне затвердження їх у законодавстві, а також реформування державного управління з метою вираження станових інтересів перед монархічною владою.

Ця тенденція знайшла своє відтворення в численних спробах обмежити самодержавство. Так, у 1730 р. група найвищих сановників імперії на чолі з князем Д.М. Голіциним спробувала, скориставшись смертю царя Петра II, нав'язати новій імператриці Анні Іоанівні умови («Кондиції»), які суттєво обмежували іiі владу[5, c. 115, 119]. Паралельно різні групи дворян протягом січня - лютого 1730 р. висунули свої проекти обмеження царської влади владою станово-представницьких установ, що репрезентували б інтереси насамперед дворянства, а також купецтва і міщан [5, c. 115].

Щодо цих проектів необхідно зазначити наступне. Їх прийнято розглядати як пам'ятки виключно російської політико-правової думки, які не стосуються історії держави і права України. Ми не погоджуємося $з$ таким поглядом і вважаємо, що ці документи безпосередньо стосуються історії української державності та права через такі моменти. По-перше, вони відображають вплив ідеї народу як шляхти (дворянства) і, відповідно, прав народу на російську політико-правову думку. Ця ідея сформувалася в Речі Посполитій і була перенесена на російський грунт за посередництва малоросів (українців) у XVII ст. По-друге, ідея обмеження царської влади владою обраних дворянством та іншими станами представницьких установ, відображена в конституційних проектах 1730 р., на нашу думку, готувала грунт для подальших реформ державного управління на українських землях Російської імперії й для відображення цієї нової управлінської системи в законодавстві вже за правління Катерини II. Конституційні проекти 1730 р. становили подальший розвиток ідеї станових прав різних соціальних груп (насамперед дворянства) перед державною владою, а отже, розвивали традицію конституціоналізму на українських землях, відображену в гетьманських статтях XVII-XVIII ст., були їх своєрідним 
продовженням.

Далі потрібно з’ясувати, наскільки становий конституціоналізм у Російській імперії в цілому й на українських землях у складі Росії зокрема був утілений у життя за царювання Катерини II. Слід розуміти, що, усвідомлюючи загрозу для своєї влади через нерозв'язаність у Російській імперії (і на підвладних ій українських землях) питання про станові, точніше станово-територіальні права й привілеї, імператриця намагалася «зіграти на випередження», не допустити широкомасштабних антиурядових виступів. Для цього Катерина II та їі радники (серед яких до речі, був i виходець з України професор права Московського університету С.Ю. Десницький) розпочали широке реформування Російської держави 3 урахуванням вимог станів, насамперед дворянства (репрезентованого на українських землях імперії колишньою козацькою старшиною).

Зміст реформ було розкрито в таких законодавчих актах імперії: «Учреждение для управления губерніями Всероссийской империи» (1775р.); «Устав благочиния или полицейский» (1782р.), «Грамота на права, вольности и преимущества благородного российского дворянства» (1785 р.) та «Грамота на права и выгоды городам Российской империи» (1785 р.) [5, с. 121, 123]. Разом вони склали своєрідну імперську конституцію, що діяла в цілому до «великих реформ» другої половини XIX ст., а окремі положення - до революції 1917 р.

Основний зміст і значення цієї «конституції» полягає у визнанні й гарантуванні державою станових прав і привілеїв та виробленні механізму участі станів (за винятком селян-кріпаків) у державному управлінні, особливо на місцевому рівні, тобто там, де влада найтісніше контактує 3 населенням. Отже для малоросів (українців) «конституція» Катерини II була продовженням гетьманських статей XVIIXVIII ст. як сукупність державних законодавчих актів, що гарантували підданим імперії їх станові права. Вони тим самим істотно обмежували державну владу, яку можна називати «самодержавною» лише у старовинному значенні цього слова: владу суверенного монарха, який не $\epsilon$ васалом якоїсь іншої держави (а зовсім не як «деспотію» монарха стосовно його підданих, особливо дворянства). На доказ цього твердження наводимо такий факт: коли наступник Катерини імператор Павло I (17961801) своєю політикою практично ліквідував станові права й вольності, це викликало державний переворот 11 березня 1801 р., що мав своїм наслідком убивство монарха i відновлення станових привілеїв.

Вивчаючи конкретні законодавчі акти, що складають «конституцію» Катерини II, слід звернути особливу увагу на «Учреждение для управления губерніями Всероссийской империи» 1775 р. [5, с. 116]. Це був перший в історії російського законодавства нормативно-правовий акт, що всебічно регулював місцеве державне управління. Саме тому він і $є$ важливим для вивчення історії держави i права українських земель у складі Російської імперії в цей період. Слід звернути увагу на правовий статус станових корпорацій, особливо дворянських, а також на визначені законом «зворотні зв'язки» цих корпорацій 3 органами й посадовими особами державної влади (як місцевої, так і центральної) і самим монархом.

Важливим моментом станової автономії була розгалужена система виборних 
станових судів, судді й засідателі яких обиралися станами й затверджувалися представниками держави на місцях - генерал-губернаторами (намісниками) [5, с. 116].

Одним із найважливіших ознак станово-територіальної автономії окремих частин імперії була децентралізація державної влади 3 перенесенням іiі найважливіших функцій зі столиці на місця - у губернії, повіти, міста. Систему місцевих владних установ і посадових осіб становили як призначені монархом чиновники, так і виборні особи від станів, особливо від дворянства. Потрібно усвідомлювати їх значення в державному механізмі імперії: відтепер здійснення державного управління на місцях значною мірою переходило до виборних станових представників, з якими змушена була рахуватись державна влада.

Ураховуючи, що імперський державний апарат на місцях виконував свої функції значно краще, ніж козацький, можна стверджувати про втілення таким чином українського ідеалу «republica bene ordinata» в Російській державі. Цей порядок був адаптований до нових, «імперських» умов. У зв’язку з цим його можна назвати малоросійською (українською) автономією в межах Росії.

Саме малоросійство в ті часи зіграло роль хранителя української національної державної традиції в умовах імперського панування й неможливості відновити козацько-гетьманську державу в найближчому майбутньому.

Висновки з изього дослідження $i$ перспективи подальших розвідок у изьому напрямі.

1. Викладання історії конституціоналізму в навчальному курсі «Історія держави i права України» повинне відповідати Конституції України. Вона демонструє взаємовплив і взаємозалежність ідей історії українського державотворення й сучасної української державності, науки й навчальної дисципліни «Історія держави і права України» й «Конституційне право України».

2. На перетині цих двох галузей знання перебуває, уважаємо, ідея історичної полідержавності українського народу. Вона, на нашу думку, належить і до історії держави і права України, і до конституційного права України.

Ïї значення для історії держави і права України полягає в розкритті змісту багатовікової історії українського державотворення як історії всіх без винятку держав на сучасній території України до 1991 р. Усі такі держави слід вважати історичними державами українського народу, оскільки він брав участь, часом дуже активну, як у процесах розповсюдження їх влади на сучасній українській території, так i в управлінні ними.

Її значення для конституційного права України полягає у створенні історичного підгрунтя для ідеї українського народу як громадян України всіх національностей i, тим самим, для збільшення легітимності української держави в очах усіх iï громадян, а не тільки етнічних українців.

3. Викладання історії конституціоналізму в навчальному курсі «Історія держави i права України» дає змогу прослідкувати історичну еволюцію ідеї обмеження й самообмеження державної влади на користь прав іiі підданих. Це свідчить не просто про багату історичну традицію конституціоналізму на території сучасної України, а 
про здатність наших предків жити в умовах дотримання законності й підтримання порядку в суспільстві й державі цивілізованими способами.

4. Історія конституціоналізму на території сучасної України в домодерний період розвитку державності та права свідчить, що основна увага тодішніх людей була зосереджена, по-перше, на питаннях взаємодії Церкви й держави (сюди ж потрібно зарахувати й питання захисту прав різних конфесій перед державною владою), подруге, на питаннях захисту станових прав різних соціальних груп, i, по-третє, на питаннях регіональних прав населення визначеної території в складі держави, до якої ця територія входила.

5. Перспективи подальших наукових розвідок у цьому напрямку, на нашу думку, полягають у такому: а) дослідження історії конституціоналізму в окремих державах до модерної епохи на території сучасної України; б) дослідження окремих проблем і періодів історії конституціоналізму в Україні.

\section{Література:}

1. Бездержавність (бездержав'я, недержавність). UPL : http: https:/histua.com.

2. «Генрікові артикули (статті)». UPL : http: Textbooks.net.ua.

3. Гончаренко В. Д., Срмолаєв В. М., Рум'янцев В. О. Історія держави і права Украйни : навч. посіб. Харків, 2013. 704 c.

4. Держава // Велика украӥнська юридична енциилопедія. У 20 m. Т. 3. Харків, 2017. С. 89-92. $336 c$.

5. Земщов Б. Н. Историягосударства и права России : учеб. пос. М. : Изд. Центр ЕАОН, 2008.

6. Єрмолаєв В. М. Правда Руська Ярослава Мудрого: до витоків і традииій вітчизняного законодавства // Проблеми законності : зб. наук. пр. Харків, 2015. Вип. 129. С. 3-10.

7. Канищев Г. Ю. Государственное управление в Украине: проблемы исследования // Матеріали VIII Міжнарод. наук.-практ. конф. «Людина, культура, техніка в новому тисячолітті». Харків, 2007. C. $48-49$.

8. Конституиія України: Закон від 28.06.1996 № 254к/96-ВР // База даних «Законодавство України»/BP України. URL: http: zakon2rada.gov.ua/laws/show/254\%D0\%BA96\% D0\%B2\%D1\%80 (дата звернення: 08.02.2012).

9. КонституцияХорватии // База даних «Конституции государств (стран) мира» UPL: http: / wordconstitutions. ru.

10.Музиченко П. Історія держави $i$ права України : навч. посіб. UPL: http: https://pidruchniki.com.

11. Пактаконвента. UPL : http: Leksika.com.ua.

12. Петришин О. В., Погорілко В. Ф. Науково-практичний коментар до Конституції Украӥни UPL : http: https: //www.twirpx.com/file/148284.

13. Привилей 1492 года - раннефеодальная Конституция Великого княжества Литовского. UPL: http: https://studfiles.net

14. Про правонаступнищтво Украӥни: Закон Украӥни від 12.09.1991 № 1543-XII // База даних «Законодавство України» / ВР України. UPL : http: zakonOrada.gov.ua/laws/shov/1543-12.

15. Статут Великого князівства Литовського, виданий у Кракові в 1588 рочі. UPL: Textbooks.net.ua/content/viev/887/17.

16. Теплов Г. Н. О непорядках, которые происходят от злоупотребления прав и обыкновений, грамотами подтвержденных Малороссии. UPL: http: www. Vostlit. Info/XVIII/Teplov/text. 


\section{References:}

1. Bezderžavnist [Statelessness], available at: https:/histua.com.

2. «Genrikoviarticuli» [Henrich's articles], available at: Textbooks.net.ua.

3. Goncharenko, V. D., Ermolaev, V. M., and Rumyantsev, V. O. (2013), Istoriya derzhavy I prava Ukrayiny [History of State and law of Ukraine], Pravo, Kharkiv.

4. Derzava //Velikaukrainskauridichna encyclopedia. T. 3. (2017) [State//Great ukrain. juridical. encyclopedia. T. 3], Pravo, Kharkiv.

5. Zemtsov, B. N. (2008), Istoria gosudarstva i prava Rossii [History of state and law of Russia], Publishing center EAON, Moscow.

6. Ermolaev, V. M. (2015), Pravda russka Yaroslava Moudrogo: do vitokiv i tradicii vitchiznanogo zakonodavstva [«Russian Thuth» bu Yaroslavtne Wise], Pravo, Kharki.

7. Kanischev, G. Y. (2007), Gosudarstvennoye upravleniye v Ukraine: problemy issledovaniya [Public administration in Ukraine: research problems], Khai, Kharkiv.

8. Konstytutsiya Ukrainy (1996) [Constitution of Ukraine], available at: http: zakon2rada.gov.ua/laws/show/254\%D0\%BA96\% D0\%B2\%D1\%80.

9. Konstytutsiya Khorvatii. [Constitution of Croatia]. Database: "Theconstitutionofthestates (countries) of the world".

10. Muzychenko, A. P., Istoriya derzhavy i prava Ukrayiny [History of State and law of Ukraine], available at: https://pidruchniki.com.

11. Paktakonventa [Convent Pact], available at: Leksika.com.ua.

12. Petrishin, O. V., Pogorilko, V.F. Naukovo - praktychnyy komentar Konstytutsiyi Ukrayiny [Scientific and practical commentary on the Constitution of Ukraine], available at: https://www.twirpx.com/file/148284.

13. Priviley 1492 goda - rannefeodal'naya Konstitutsia Velikogo Knyazhestva litovskogo[Privilege of 1492 - the early feudal Constitution of Grand Duchy of Lithuania], available at: https://studfiles.net.

14. Pro pravonastupnytstvo Ukrainy: ZakonUkrayiny vid 12.09.1991№ 1543-XII[Of the succession of Ukraine: law of Ukraine of 12.09.1991oo 1543-XII], available at: http: zakonOrada.gov.ua/laws/shov/154312.

15. Statut Velykoho Knyazivstva Lytovs'koho, vydanyy v Krakovi 1588 roku [Statute of Grand Duchy of Lithuania was published in Cracowin 1588], available at:Textbooks.net.ua/content/viev/887/17.

16. Teplov, G. N. O neporyadkakh, kotoryye proiskhodyat ot zloypotreblenia pravami, gramotami podtverzhdennymi Malorossii [About disorders that occur from the abuse of rights, letters confirmed by the Little Russe], available at: www. Vostlit. Info/XVIII/Teplov/text.

\section{Grygory Kanishchev}

\section{CONSTITUTIONALISM IN TEACHING OF «HISTORY OF STATE AND LAW OF UKRAINE» (ANTIQUITY AND THE MIDDLE AGES)}

History of State and law of Ukraine can be considered as one of the leading academic disciplines for modern lawyers. Its purpose is to familiarize professionals with the historical experience of the development of statehood on the territory of modern Ukraine that directly or indirectly impacts the current status and the quality of the public authority in our country, the relationship between the State and citizens, the situation in Ukraine in the international arena, its image in the world, etc.

The role of history of State and law of Ukraine here is mapping the processes of historical evolution of human relationships and the State of modern Ukrainian territory. This 
includes compliance with State rights, in particular political struggle of people for their rights both peacefully and violently (through armed revolt against the authorities) etc. In this connection, training courses and research on history of State and law of Ukraine should pay significant attention to the evolution of public authorities as a result of the struggle of people for their rights.

Thus, the purpose of the article is to cover the history of constitutionalism on the territory of modern Ukraine in premodern period of development of the Ukrainian State and law. The task is to disclose the relationship of history of State and law and constitutional law of Ukraine through the analysis of the content of State legislative acts, which served as constitutions for the population that inhabited Ukrainian lands at that time in various states.

Thus, below we specify our findings from the current research and prospects of further research:

1. Teaching History of constitutionalism in the training course «History of State and law of Ukraine» must conform to the Constitution of Ukraine as the Main Law of the State and the benchmark for social activities.

2. Teaching History of constitutionalism in the training course «History of State and law of Ukraine» gives an opportunity to examine the historical evolution of the idea of the limit and self-restriction of State power in favor of the rights of its citizens. It is not just because of the rich historical tradition of constitutionalism on the territory of modern Ukraine, but due to the ability of our ancestors to live in the conditions of observance to the law and maintenance of order in society and the State by civilized ways.

3. The prospects of subsequent scientific researches in this field, to our opinion, are the following: a) research of history of constitutionalism in separate states on the territory of modern Ukraine; b) research of certain problems and periods of history of constitutionalism in Ukraine.

Keywords: constitutionalism, human rights, The Constitution of Ukraine, historical polistatehood of the Ukrainian people.

\section{Григорій Каніщцев}

\section{КОНСТИТУЦІОНАЛІЗМ У ВИКЛАДАННІ «ІСТОРІЇ ДЕРЖАВИ І ПРАВА УКРАЇНИ» (ДОМОДЕРНИЙ ПЕРІОД)}

Історію держави і права України можна вважати однією з провідних навчальних дисциплін для сучасних юристів. Її метою є ознайомлення майбутніх фахівців із тим історичним досвідом розвитку державності та права на території сучасної України, що прямо або опосередковано впливає й на сучасний стан і якість публічної влади в нашій державі, на відносини між державою і громадянами, на становище України на міжнародній арені, їі імідж у світі тощо.

Роль історії держави і права України тут полягає у відображенні процесів історичної еволюції взаємин людини й держави на сучасній українській території. Це стосується дотримання державою прав громадян, зокрема політичних, боротьби людей за свої права як мирним, так i насильницьким шляхом (через збройне 
повстання проти державної влади) тощо. Велике значення у зв'язку з цим, на нашу думку, має відображення в навчальних курсах і наукових дослідженнях 3 історії держави і права України еволюції публічної влади внаслідок боротьби людей за свої права.

Mema cmammi: висвітлення історії конституціоналізму на території сучасної України в домодерний період розвитку української державності та права. Завдання cmammi: розкриття взаємозв'язку історії держави і права України та конституційного права України через аналіз змісту державних законодавчих актів, які мали значення конституцій для тодішнього населення українських земель у складі різних держав.

Висновки з цьього дослідження й перспективи подальших розвідок:

1. Викладання історії конституціоналізму в навчальному курсі «Історія держави i права України» повинне відповідати Конституції України як основному закону держави та орієнтиру для суспільної діяльності.

2. Викладання історії конституціоналізму в навчальному курсі «Історія держави i права України» дає змогу прослідкувати історичну еволюцію ідеї обмеження й самообмеження державної влади на користь прав іiі підданих. Це свідчить не просто про багату історичну традицію конституціоналізму на території сучасної України, а про здатність наших предків жити в умовах дотримання законності й підтримання порядку в суспільстві й державі цивілізованими способами.

3. Перспективи подальших наукових розвідок у цьому напрямку, на нашу думку, полягають у наступному: а) дослідження історії конституціоналізму в окремих державах домодерної епохи на території сучасної України; б) дослідження окремих проблем і періодів історії конституціоналізму в Україні.

Ключові слова: конституціоналізм, права людини, Конституція Украӥни, історична полідержавність украӥнського народу.

Kanishchev Grygory - Ph.D. in History, Associate Professor, Associate Professor of the Department of Law Faculty of Humanities of the National Aerospace University «Kharkiv Aviation Institute».

Каніщев Григорій - кандидат історичних наук, доцент, доцент кафедри права гуманітарного факультету Національного аерокосмічного університету ім. М. Є. Жуковського «Харківський авіаційний інститут».

e-mail: kanischev.g@gmail.com

Надійшла до редакції 13.05.2019. Розглянута на редколегії 14.06.2019.

\section{Рецензенти:}

Доктор філософських наук, професор, декан гуманітарного факультету Національного аерокосмічного університету ім. М. Є. Жуковського «ХАІ» Копилов В.О.

Доктор філософських наук, професор, професор кафедри філософії Харківського національного університету Повітряних Сил імені Івана Кожедуба Панфілов О.Ю. 